\title{
Complementary and Alternative Medicine in Patients with Primary Immunodeficiency
}

\author{
Primer İmmün Yetmezliği Olan Hastalarda Tamamlayıcı ve Alternatif \\ Tedavi Kullanımı
}

Celal ÖZCAN, Ayşe METiN, Mustafa ERKOÇOĞLU, Tayfur GiNiŞ, Ayşenur KAYA, Can Naci KOCABAŞ

Ankara Children's Health and Diseases Hematology and Oncology, Training and Research Hospital, Pediatric Allergy and Immunology Clinic, Ankara, Turkey

\begin{abstract}
Objective: It has been reported that the use of complementary and alternative medicine is increasing in childhood. The aim of this study was to determine the frequency of CAM usage in children with primary immunodeficiency.
\end{abstract}

Material and Methods: A survey was conducted to the parents of patients between the ages of 2.5 and 18 years diagnosed with primary immunodeficiency.

Results: Seventy-six (64.4\%) of patients had used CAM in the last 12 months. We could not demonstrate any relationship between CAM usage and age, sex, duration of follow up and type of primary immunodeficiency. CAM usage was significantly low both in patients who came to the visits regularly and in patients who underwent a specific treatment with intravenous immune globulin (IVIG), interferon $\gamma$ (IFN- $\gamma$ ) or granulocyte colony stimulating factor (G-CSF) $(\mathrm{P}=0.019$ and $\mathrm{P}=0.033)$.

Conclusion: In the present study it was shown that use of CAM is high in patients with primary immunodeficiency who do not attend their regular control visits at the hospital and who are not under a specific medical treatment.

Key Words: Alternative medicine, Herbal medicine, Diet habits, Immune deficiency

\section{ÖZET}

Amaç: Tamamlayıcı ve alternatif tedavi kullanımını çocuklarda giderek artıı̆ı bildirilmektedir. Bu çalışmanın amacı, primer immün yetmezliği olan çocuklarda tamamlayıcı ve alternatif tedavi (TAM) kullanım sıklığını belirlemektir.

Gereç ve Yöntemler: Primer immün yetmezlik tanısılla takipli 2,5 ile 18 yaş arasında olan hastaların anne veya babalarına tamamlayıcı ve alternatif tedavi ile ilgili soruları içeren anket uygulandı.

Bulgular: Hastaların 76'sı (\%64.4) son 12 ayda tamamlayıcı ve alternatif tedavi kullanmışı.ı. Tamamlayıcı ve alternatif tedavi kullanımının yaș, cinsiyet, ortalama takip süresi ve primer immün yetmezlik türü ile herhangi bir ilișkisi yok iken, kontrollere düzenli gelen hastalarda ve intravenöz immünglobulin (IViG), interferon- $\gamma$ (IFN- $\gamma$ ) veya granülosit koloni sitimüle edici faktör (G-CSF) ile rutin tedavi yapılan hastalarda TAM kullanımı, anlamlı olarak daha düşük bulundu ( $P=0,019$ ve $\mathrm{P}=0,033)$.

Sonuç: Kontrollere düzenli gelmeyen ve rutin periyodik tıbbi tedavi almayan primer immün yetmezliği olan hastalarda TAM kullanımının yüksek olduğu görülmektedir.

Anahtar Sözcükler: Alternatif tedavi, Bitkisel tedaviler, Diyet allşkanlıkları, İmmün yetmezlik

\section{INTRODUCTION}

Complementary and alternative medicine (CAM) includes a series of medications that are used as an addition or an alternative to conventional medical treatment (1). It has been reported that the use of CAM is increasing in childhood $(2,3)$.

Generally it is thought that the use of CAM is harmful (4). It was reported that people who use CAM have more negative responses towards medical treatment compared to those who do not use CAM (5). Furthermore it has been determined that the ceasing, refusal or delay of medical treatment is related to the use of CAM (6). For these reasons physicians need to know whether or not the patients are using CAM.

In addition, it has been reported that frequent use of CAM is related to chronic, recurrent and incurable diseases (7-12). There are few studies published on the use of CAM 
in patients with primary immunodeficiency compared to the other chronic diseases in childhood. In this study we aimed to determine the frequency of CAM usage in children with primary immunodeficiency diseases.

\section{MATERIAL and METHODS}

A survey was conducted to parents of patients between ages of 2.5 and 18 years diagnosed with a primary immunodeficiency disease (PID) at our Pediatric Immunology Unit outpatient clinic between April 2012 and August 2012. Patients were diagnosed and classified according to the clinical and laboratory criteria of PID reported by the IUIS Primary Immunodeficiency Diseases Classification Committee (13). This study was approved by the Ankara Children's Hematology Oncology Training and Research Hospital Local Ethics Committee and a written informed consent was obtained from their parents.

The survey questions were asked to the parents face to face. The questions were about their sociodemographic status (age, sex, the family's monthly income, and the parent's education level), primary immunodeficiency (history, diagnosis, duration of follow up, specific medical treatment) and CAM usage as to whether or not they have used it for the last 12 months after the PID diagnosis. In case they were using it, we asked which CAM form or forms they were using, who advised it, whether or not they had been informed about CAM by the physicians, and whether or not there was any change in the frequency of infection (markedly decreased, minimal decreased or unchanged) after starting CAM according to preformed questionnaire by Karali and colleagues (22). Parental education level was scored as the last school they graduated from: 1. Primary school; 2. Secondary school; 3. High school; 4. University.

\section{Statistical analysis}

Statistical analysis was performed using the SPSS version 15.0 (SPSS Inc., Chicago, IL, USA). Values were either provided as numbers and percentages, or as mean \pm standard deviation, where applicable. Comparisons of the frequency of variables between CAM and non-CAM groups were made using the Chisquare test, Fisher's exact test and student's t-test. A p-value of $\leq 0.05$ was considered indicative of statistical significance.

\section{RESULTS}

A total of 118 PID patients with a mean age of $10.4 \pm 4.7$ years were included in the study. The mean follow up period was $3.5 \pm 3.9$ years (between 1 and 15 years) and $60.2 \%$ of them were male. The general characteristics of patients are shown in Table I. Within the study group, 84 patients $(71.2 \%)$ had an antibody deficiency syndrome, 18 (15.3\%) had combined T and B cell immunodeficiency, 15 (12.7\%) had phagocyte number or function defect and one patient $(0.8 \%)$ had complement deficiency (Table II).
Table I: General characteristics of patients $(\mathrm{N}=118)$.

\begin{tabular}{|c|c|}
\hline Characteristic features & $\begin{array}{c}\text { Number of Patients } \\
\mathrm{n}(\%)\end{array}$ \\
\hline Sex (male) & $71(60.2)$ \\
\hline Age, year, (mean $\pm S D)$ & $10.2 \pm 4.5$ \\
\hline $\begin{array}{l}\text { Mean follow up period, year, } \\
\text { (mean } \pm \text { SD) }\end{array}$ & $3.5 \pm 3.9$ \\
\hline Monthly family income $(<400 \$)$ & $26(22.0)$ \\
\hline \multicolumn{2}{|l|}{ Mother's education level } \\
\hline Illiterate & $4(3.4)$ \\
\hline Primary school & $69(58.5)$ \\
\hline Secondary school & $13(11.0)$ \\
\hline High school & $27(22.9)$ \\
\hline University & $5(4.2)$ \\
\hline \multicolumn{2}{|l|}{ Father's education level } \\
\hline Illiterate & $2(1.7)$ \\
\hline Primary school & $31(26.3)$ \\
\hline Secondary school & $33(27.9)$ \\
\hline High school & $35(29.7)$ \\
\hline University & $17(14.4)$ \\
\hline CAM use & $76(64.4)$ \\
\hline
\end{tabular}

Table II: Distribution of primary immunodeficiency among patients.

\begin{tabular}{|l|c|}
\hline Diagnosis & $\begin{array}{c}\text { Number of Patients } \\
\text { N=118 (\%) }\end{array}$ \\
\hline Antibody deficiency & $84(71.2)$ \\
\hline Selective IgA deficiency & $33(28.0)$ \\
\hline $\begin{array}{c}\text { Transient } \\
\text { Hy77pogammaglobulinemia }\end{array}$ & $19(16.1)$ \\
\hline IgG subclass deficiency & $13(11.0)$ \\
\hline Partial lgA deficiency & $11(9.3)$ \\
\hline Common variable & $6(5.1)$ \\
\hline immunodeficiency & $2(1.7)$ \\
\hline X-linked agammaglobulinemia & $18(15.3)$ \\
\hline Combined immunodeficiency & $5(4.2)$ \\
\hline Hyper lgE syndrome & $5(4.2)$ \\
\hline Ataxia telengiectasia & $3(2.5)$ \\
\hline Wiskot-Aldrich syndrome & $3(2.5)$ \\
\hline DiGeorge syndrome & $2(1.7)$ \\
\hline $\begin{array}{l}\text { Autoimmune lymphoproliferative } \\
\text { disease }\end{array}$ & $15(12.7)$ \\
\hline $\begin{array}{l}\text { Phagocyte number or function } \\
\text { defect }\end{array}$ & $7(5.9)$ \\
\hline Chronic granulomatous disease & $7(5.9)$ \\
\hline Congenital neutropenia & $1(0.8)$ \\
\hline IL-12 receptor beta deficiency & $1(0.8)$ \\
\hline Complement deficiency & \\
\hline
\end{tabular}


Seventy-six (64.4\%) patients had used CAM in the last 12 months. Among the patients who used CAM, 40 patients (52.6\%) had used only one form of CAM, 22 (29\%) had used two forms of CAM, 12 (15.8\%) had used three forms of CAM and two (2.6\%) patients used four different forms of CAM. In our study the most commonly used non-herbal CAM forms were honey (16.9\% of the patients) and carob syrup (12.7\%)

Table III: Distribution of herbal and non-herbal products used as CAM therapy.

\begin{tabular}{|c|c}
\hline Non-herbal Products & $\begin{array}{c}\text { Number of Patients } \\
\mathbf{N}=\mathbf{1 1 8}(\mathbf{\%})\end{array}$ \\
\hline Honey & $51(43.2)$ \\
Carob syrup & $20(16.9)$ \\
\hline Royal jelly & $15(12.7)$ \\
\hline Quail eggs & $12(10.2)$ \\
\hline Fish oil & $9(7.6)$ \\
\hline Grape syrup & $7(5.9)$ \\
\hline Chestnut honey & $6(5.1)$ \\
\hline Mesir paste & $4(3.4)$ \\
\hline Herbal products & $1(0.8)$ \\
\hline Herbal tea & $38(32.2)$ \\
\hline Ginger & $15(12.7)$ \\
\hline Black Cumin & $9(6.8)$ \\
\hline Lemon - peppermint & $5(4.2)$ \\
Cinnamon & $3(2.5)$ \\
\hline Grape leaf juice & $2(1.7)$ \\
\hline Licorice & $1(0.8)$ \\
Grape seed & $1(0.8)$ \\
\hline Stinging Nettle & $1(0.8)$ \\
\hline Linseed & $1(0.8)$ \\
\hline Amulet & $1(0.8)$ \\
\hline
\end{tabular}

whereas the herbal forms mostly used were herbal tea (12.7\%) and ginger (6.8\%) (Table III).

Among the parents of patients who used CAM, 53.9\% (41) of them had been informed about CAM through their relatives or friends, 31.6\% (24) of them learned through media (television, newspaper and internet), in 9.2\% (7) of them CAM was suggested by their physicians and in 5.3\% (4) of them it was suggested by a pharmacist.

$52.6 \%$ (40) of the parents explained the reason for using CAM as a suggestion of a trusted person, $40.8 \%$ (31) of them it was a personal belief in the CAM methods and $6.6 \%$ (5) of them used CAM because of the failure of the other medications used. Eighty-five (72\%) parents wanted to get information about the usefulness of CAM from their physicians, 48 (56.5\%) of them said that their physician did not have any knowledge, 29 (34.1\%) said that their physician found CAM unnecessary and $8(9.4 \%)$ said that their physician has recommended CAM.

It is reported that in $48.7 \%$ (37) of patients who use CAM there was no change in frequency of infection, in $48.7 \%$ (37) of the patients there was minimal decrease in frequency of infection and in $2.6 \%$ (2) of the patients there was a prominent decrease in frequency of infection. Parents were reported that there was a decrease in frequency of infection after CAM in 51.7\%, $50 \%$ and $50 \%$ of antibody deficiency patients, combined immunodeficiency patients and patients with phagocyte number or function defects respectively $(\mathrm{P}=0.885)$. With respect to the type of CAM, parents reported that $52.2 \%$ of patients who used only herbal products, $47.2 \%$ of patients who used only non-herbal products, and $73.3 \%$ of patients who used both had experienced reduced frequency of infection $(P=0.294)$.

The use of CAM was not found to be related to the parental education level. However, the usage of CAM was higher in patients whose families had a monthly income below the minimum wage (less than $400 \$$ ) than in patients whose families had a monthly income above the minimum wage $(84.6 \%$ and $58 \%$, respectively, $\mathrm{P}=0.025$ ).

Table IV: Comparison of the CAM and Non-CAM groups.

\begin{tabular}{|c|c|c|c|}
\hline & $\begin{array}{l}\text { CAM } \\
n=76\end{array}$ & $\begin{array}{c}\text { Non-CAM } \\
n=42\end{array}$ & $\mathbf{P}$ \\
\hline Age, year (mean $\pm S D)$ & $10.0 \pm 4.8$ & $10.5 \pm 4.2$ & 0.627 \\
\hline Antibody deficiency & $58(76.3)$ & $27(64.3)$ & 0.160 \\
\hline Combined ID & $10(13.2)$ & $8(19.1)$ & 0.412 \\
\hline Regular visits & $25(\% 32.9)$ & $30(\% 71.4)$ & 0.019 \\
\hline Patients who are given routine medical treatment & $12(15.8)$ & $15(35.7)$ & 0.033 \\
\hline Monthly income (<400 \$) & $22(29.0)$ & $4(9.5)$ & 0.025 \\
\hline Mother's education level & $1.7 \pm 1.1$ & $1.6 \pm 0.9$ & 0.633 \\
\hline
\end{tabular}


Although there was no relation between the use of CAM and age, sex, duration of follow up and type of primary immunodeficiency, the use of CAM was significantly lower in patients who came to visits regularly and in patients who had continuous specific treatment with intravenous immunoglobulin (IVIG), interferon $\gamma(\mathrm{IFN}-\gamma)$ or granulocyte colony stimulating factor (G-CSF) ( $\mathrm{P}=0.019$ and $\mathrm{P}=0.033$ ) (Table IV).

\section{DISCUSSION}

The frequency of CAM usage in chronic diseases varies between $23 \%$ and $81 \%$ during childhood $(9,14-21)$. In our country, Karali and colleagues (22) reported that the use of CAM was $83.7 \%$ in patients with common variable immunodeficiency, while it was reported as $49 \%$ in asthmatic patients in another study (23). In our study, $64.4 \%$ of patients with primary immunodeficiency have been used CAM in the past 12 months. As far as we know, our study is the second to be done on the use of CAM in children with primary immunodeficiency. Unlike the previous study done in our country by Karali and colleagues (22), we investigated the frequency of CAM usage in the last 12 months in all types of primary immunodeficiencies. According to the results of our study, as compared to their data, the frequency of CAM usage seems to be higher in patients with PID than in patients with the other chronic diseases.

Some studies have found that the use of CAM was higher in children whose mothers had a high education level, whereas Shen and colleagues did not find a relation between the use of CAM and parental education level. Similar to the previous study from our country, we also did not find a relation between the use of CAM and parental education levels (24-27).

Shen et al. (27) also reported that as the family income decreases, the frequency of CAM usage increases. However in a study done in patients with common variable immunodeficiency, it was reported that socioeconomic status does not affect the use of CAM (22). In our study, the use of CAM in families with a monthly income less than the minimum wage (less than 400 \$) was significantly high.

It has been reported that the use of CAM is significantly high in children with poor asthma control $(23,27,28)$. In our study the frequency of CAM usage was significantly high in patients who have not come visits regularly and have taken routine medication including IVIG, IFN- $\gamma$ or G-CSF as compared to patients who come to visits regularly and who have routine medical treatment. It seems that patients who have to take specific medication and come for follow-up regularly may be well informed about their disease which may prevent them from considering any alternative cure. Increased use of CAM in children whose families have low monthly income might be due to their low economic condition that affects their coming for regular visits negatively and causing the families to seek alternative medication.
Karali et al. (22) reported that $44.4 \%$ of common variable immunodeficiency patients who use CAM had a reduced frequency of infection. In our study, in $51.3 \%$ of patients who use CAM, their parents said that their children's frequency of infection had decreased. However a big portion of these patients (94.9\%) are those who said that the reduction in frequency of infection was minimal. There was no relation between the reduction in frequency of infection and type of primary immunodeficiency or form of CAM used. The minimal decrease in infections reported by the parents could be thought to be due to a placebo effect or parental impression.

It is reported that most families in the western countries learn about CAM through the media (29). However, similar to previous data from our country, this study showed that CAM usually starts as an advice from relatives or friends $(22,23)$. In our study it was seen that there was little advice taken from physicians on use of CAM and that most physicians were not interested in the issue of CAM use. Moreover, the parents of most of our patients who use CAM said that they started using it by listening to a reliable person. Education about CAM is not given in medical faculties in Turkey. We believe that education on CAM in medical faculties is necessary to inform the patients and their families sufficiently in order to prevent its potential harmful effects.

In conclusion, it is seen that use of CAM is high in patients with primary immunodeficiency. Furthermore, this rate is higher in patients with primary immunodeficiency who do not come for regular follow-ups and do not take specific medical treatment.

\section{REFERENCES}

1. Defining and describing complementary and alternative medicine. Panel on Definition and Description, CAM Research Methodology Conference, April 1995. Altern Ther Health Med 1997;3:49-57.

2. Kemper KJ, Vohra S, Walls R; American Academy of Pediatrics. The use of complementary and alternative medicine in pediatrics. Pediatrics 2008;122:1374-86.

3. Ernst E. Prevalence of complementary/alternative medicine for children: A systematic review. Eur J Pediatr 1999;158:7-11.

4. Featherstone C, Godden D, Selvaraj S, Emslie M, Took-Zozaya $M$. Characteristics associated with reported CAM use in patients attending six GP practices in the Tayside and Grampian regions of Scotland: A survey. Complement Ther Med 2003;11:168-76.

5. Hameen-Anttila KP, Niskala UR, Siponen SM, Ahonen RS. The use of complementary and alternative medicine products in preceding two days among Finnish parents - a population survey. BMC Complement Altern Med 2011;11:107.

6. Cohen $\mathrm{MH}$, Kemper KJ. Complementary therapies in pediatrics: A legal perspective. Pediatrics 2005;115:774-80.

7. Hanssen B, Grimsgaard S, Launso L, Fonnebo V, Falkenberg T, Rasmussen NK. Use of complementary and alternative medicine in the Scandinavian countries. Scand J Prim Health Care 2005;23: 57-62. 
8. Al-Windi A. Determinants of complementary alternative medicine (CAM) use. Complement Ther Med 2004;12:99-111.

9. Mazur LJ, De Ybarrondo L, Miller J, Colasurdo G. Use of alternative and complementary therapies for pediatric asthma. Tex Med 2001;97:64-8.

10. Boon HS, Olatunde F, Zick SM. Trends in complementary/ alternative medicine use by breast cancer survivors: Comparing survey data from 1998 and 2005. BMC Womens Health 2007;7:4.

11. Ernst E, Cassileth BR. The prevalence of complementary/alternative medicine in cancer: A systematic review. Cancer 1998;83:777-82.

12. McCann LJ,Newell SJ. Survey of paediatric complementary and alternative medicine use in health and chronic illness. Arch Dis Child 2006;91:173-4.

13. Notarangelo LD, Fischer A, Geha RS, Casanova JL, Chapel H, Conley ME, et al. Primary immunodeficiencies: 2009 update. J Allergy Clin Immunol 2009;124:1161-78.

14. Samdup DZ, Smith RG, II Song S. The use of complementary and alternative medicine in children with chronic medical conditions. Am J Phys Med Rehabil 2006;85:842-6.

15. Shenfield G, Lim E, Allen H. Survey of the use of complementary medicines and therapies in children with asthma. J Paediatr Child Health 2002;38:252-7.

16. Hagen LE, Schneider R, Stephens D, Modrusan D, Feldman BM. Use of complementary and alternative medicine by pediatric rheumatology patients. Arthritis Rheum 2003;49:3-6.

17. Hurvitz EA, Leonard C, Ayyangar R, Nelson VS. Complementary and alternative medicine use in families of children with cerebral palsy. Dev Med Child Neurol 2003;45:364-70.

18. Friedman T, Slayton WB, Allen LS, Pollock BH, Dumont-Driscoll M, Mehta P, Graham-Pole J. Use of alternative therapies for children with cancer. Pediatrics 1997;100:1.
19. Sinha D, Efron D. Complementary and alternative medicine use in children with attention deficit hyperactivity disorder. J Paediatr Child Health 2005;41:23-6.

20. Levy SE, Hyman SL. Use of complementary and alternative treatments for children with autistic spectrum disorders is increasing. Pediatr Ann 2003;32:685-91.

21. Lemay JF, Amin A, Pacaud D. Complementary and alternative medicine use in children and adolescents with type 1 diabetes. Paediatr Child Health 2011;16:468-72.

22. Karali Y, Saglam H, Karali Z, Kilic SS. The use of complementary and alternative medicine in patients with common variable immunodeficiency. J Investig Allergol Clin Immunol 2011;21:480-3.

23. Orhan F, Sekerel BE, Kocabas CN, Sackesen C, Adalioglu G, Tuncer A. Complementary and alternative medicine in children with asthma. Ann Allergy Asthma Immunol 2003;90:611-5.

24. MacLennan AH, Wilson DH, Taylor AW. Prevalence and cost of alternative medicine in Australia. Lancet 1996;347:569-73.

25. Astin JA. Why patients use alternative medicine: Results of a national study. JAMA 1998;279:1548-53.

26. Eisenberg DM, Davis RB, Ettner SL, Appel S, Wilkey S, Van Rompay $\mathrm{M}$, et al. Trends in alternative medicine use in the United States, 1990-1997: Results of a follow-up national survey. JAMA 1998;280:1569-75.

27. Shen J, Oraka E. Complementary and alternative medicine (CAM) use among children with current asthma. Prev Med 2012;54: 27-31.

28. Shaw A, Noble A, Salisbury C, Sharp D, Thompson E, Peters TJ. Predictors of complementary therapy use among asthma patients: Results of a primary care survey. Health Soc Care Community 2008;16:155-64.

29. Cassileth BR, Chapman CC. Alternative and complementary cancer therapies. Cancer 1996;77:1026-34. 